\title{
CURRENT STATE OF THE
} APPLICATION OF ARTIFICIAL INTELLIGENCE IN RELIABILITY AND MAINTENANCE

\author{
Slavko J. Pokorni \\ Information Technology School, Belgrade, Republic of Serbia, \\ e-mail: slavko.pokorni@its.edu.rs, \\ ORCID iD: (Dhttp://orcid.org/0000-0002-3173-597X
}

DOI: 10.5937/vojtehg69-30434; https://doi.org/10.5937/vojtehg69-30434

FIELD: Logistics, IT

ARTICLE TYPE: Original scientific paper

\begin{abstract}
:
Introduction/purpose: At the end of 2019, the Government of the Republic of Serbia adopted the Strategy for the Development of Artificial Intelligence in the Republic of Serbia for the 2020-2025 period. This was a motivation for the author of this paper to try to give an overview of the current artificial intelligence (Al) applications in the field of reliability and maintenance, as well as its future applications.

Methods: The overview is done mainly using available literature, mostly from the Science Direct database, using abstracts generally, and in some cases whole papers.

Results: The result of this research is an overview of the artificial intelligence applications in the field of reliability and maintenance in the past thirty years. It also showed that Al systems can also be unreliable and need maintenance.

Conclusion: Artificial intelligence is and can be applied in reliability and maintenance. The research of available literature showed that $A l$ is more applied in maintenance than in reliability. The progress in Al is inevitable, so it is important to understand its potentials for application in reliability and maintenance as well as its possible drawbacks.
\end{abstract}

Key words: artificial intelligence, reliability, maintainability, maintenance.

\section{Introduction}

The fact that the Government of the Republic of Serbia adopted the Strategy for the Development of Artificial Intelligence in the Republic of Serbia for the 2020-2025 period (Government of the Republic of Serbia, 2019), and that the author of this paper was a coauthor of a conference 
paper in 2003 in which a posibility of improvement of jet engine diagnostics by applying neural networks was suggested (Siladić et al, 2003), and the fact that the author of this paper has been working in the area of reliability and maintainability as a professor and practitioner for more than thirty years was a motivation to try to give an overview of the current applications of artificial intelligence (Al) in the field of reliability and maintenance as well as its future applications.

Since there is information that Al can also fail (Bathaee, 2018), how to avoid $\mathrm{Al}$ to fail is also discussed.

The ultimate objective of this paper is to see possibilities of $\mathrm{Al}$ application to achieve more effective reliability and maintenance.

The definition of artificial intelligence (Al) is given first followed by the definition of reliability and maintainability which is briefly discussed; after that, the application of $\mathrm{Al}$ in the area of reliability and maintenance is given in the paper, and, finally, how to avoid Al failure is discussed as well as how to maintain it, based on the available literature. The literature review was done using the Science Direct database search using the key term artificial intelligence, and then mostly using abstracts, and in some cases whole papers.

This paper is also based on the paper accepted and presented at the OTEH 2020 Conference (Pokorni, 2020).

\section{Artificial Intelligence}

There is no generally accepted definition of artificial intelligence (Government of the Republic of Serbia, 2019). According to the Encyclopedia Britannica dictionary (Copeland, 1998) artificial intelligence is the ability of a digital computer or computer-controlled robot to perform tasks commonly associated with intelligent beings. According to the Merriam-Webster dictionary (Merriam-Webster, 2020), Al is a branch of computer science dealing with the simulation of intelligent behavior in computers, or the capability of a machine to imitate intelligent human behavior.

In (Government of the Republic of Serbia, 2019), the accepted definition of $\mathrm{Al}$ is also used in (European Commission, 2019): "Artificial intelligence $(\mathrm{Al})$ refers to systems that display intelligent behavior by analyzing their environment and taking actions - with some degree of autonomy - to achieve specific goals."

In (European Commission, 2019), it is also stated that "Al-based systems can be purely software-based, acting in the virtual world (e.g. voice assistants, image analysis software, search engines, speech and 
face recognition systems) or Al can be embedded in hardware devices (e.g. advanced robots, autonomous cars, drones or Internet of Things applications)."

Obviously, the essential word is intelligence. That word is also discussed in (European Commission, 2019) where it is considered as "a vague concept", studied by different research in different scientific disciplines, and that "Al researchers use mostly the notion of rationality", which "refers to the ability to choose the best action to take in order to achieve a certain goal, given certain criteria to be optimized and the available resources". In accordance with that, in (European Commission, 2019), an updated definition of $\mathrm{Al}$ is proposed.

Artificial intelligence was founded as an academic and scientific discipline in the middle of fifties of the last century, and since then development has gone in different directions, being divided in sub-fields. Therefore, it is not a surprise that the definition of Al has been changed during time.

In the history of $\mathrm{Al}$, there have been ups and downs, starting with the logic-based approach (during the 1950s and 1960s), the knowledgebased expert systems approach (1970s and 1980s), and the data-based approach (since 2000) years onwards - with periods of disappointment and reduced investment (Government of the Republic of Serbia, 2019). In the last decades, Al is defined as a study of intelligent agents - any device that percepts its environment and takes actions (by learning or using knowledge) to achieve its goals.

The term artificial intelligence is frequently applied to the project of developing systems endowed with the intellectual processes characteristic of humans, such as the ability to reason, discover meaning, generalize, or learn from past experience (Copeland, 1998). That is also the case in the area of reliability prognostic and maintenance management. So the goal can be, more or less, replacing human reasoning with machine reasoning with fewer errors and faster decision making.

Essentially, the use of $\mathrm{Al}$ is an attempt to replace human intelligence with machine intelligence. Because of that, sometimes, Al is called machine intelligence.

Progress in $\mathrm{Al}$ is evident in many areas, especially in the last decade. It seems that the area of reliability and maintainability is not an exception. 


\section{Reliability and maintenance}

Reliability is defined as the ability of an item to perform a required function under stated conditions for a stated period of time (Bauer \& Adams, 2012).

Maintenance is usually characterized with maintainability which refers to the ability how fast and easy an item can be fixed and modified.

Quantitatively, reliability and maintainability are expressed in probability, and both are very important in reducing downtime and operational and maintenance cost of an item or a system. Reliability and maintenance are mutually connected. Higher reliability means less costly maintenance.

High reliability is very important, especially in professional equipment, and it comprises hardware reliability, software reliability, and human reliability (Pokorni, 2018).

Reliability prediction has been done for almost 60 years, mostly by MIL-HDBK-217, but about 30 years ago, it was identified that new approaches are needed (Pokorni, 2016).

Can AI help to solve these problems, or can Al solve these problems better than people can?

Reliability is built in during design, provided in production and supported in use. It is also connected with cost. More reliable equipment is more expensive, but more reliable equipment is also cheaper for maintenance.

Reliability is also connected with the process of production and use or exploitation of the equipment which is designed to be reliable.

The right maintenance can save both cost and downtime, and achieve higher availability. Different maintenance strategies are in use. The basic ones are corrective (reactive, replacing an item after it fails) and preventive (proactive, replacing an item before it fails) maintenance. More used in modern equipment are predictive maintenance or condition monitoring (just in time maintenance, optimization, the best of corrective and preventive maintenance, replacing an item which is close to failure). Also, combinations of the previously mentioned ones are used. Such a combination is, for example, reliability-centered maintenance.

As connectivity and data accessibility become cheaper and more widespread nowadays, many companies are looking at predictive maintenance, or condition-based maintenance, powered by machine learning and analytics (Uptake, 2020). Obviously, there is a place for the application of Al. 


\section{Al in reliability and maintenance}

According to the available literature, studied for this work, the application of artificial intelligence in reliability and maintenance started about forty years ago.

At the end of the eighties of the previous century, the Rome Air Development Center (RADC) investigated a so-called Smart BIT - a program of research of development and the application of $\mathrm{Al}$ techniques to effect built-in test (BIT) improvement (Richards, 1989), for diagnosis and management of faults.

Twenty years ago, the author of this paper was involved in one attempt to propose applying an intelligent system for the maintenance of a jet engine. In the abstract of this work (Siladić et al, 2003), it is concluded that continuous monitoring of the jet engine working process is considered to be one of the most efficient methods for engine condition assessment, and that the integration of airplane and jet engine built-in information-displaying systems with nondestructive testing, spectral oil analysis, and total accumulating cycle into a diagnostic system has shown to be a reliable method of establishing a specific form of jet engine oncondition maintenance. However, in spite of that, such kind of a diagnostic system suffers from the absence of prognostic capability which is necessary to predict future engine components behavior; therefore, there is a need to upgrade these systems with intelligent features that are able to recognize error patterns and make automatic decisions about engine work.

In (Singh \& Wang, 2008), it is stated that artificial intelligence techniques have drawn much attention in dealing with complex and challenging problems in power systems, and that reliability evaluation is a type of representative applications. In that paper, some concepts on reliability evaluation based on population-based intelligent search as well as a neural network enhanced Monte Carlo simulation were presented. Also, some case studies were presented to demonstrate the effectiveness of the proposed methods. According to that paper, it appears that the intelligence based methods hold promise for reliability studies and deserve to be further investigated.

In (Singh \& Wang, 2008), the conceptual basis of an overall reliability evaluation process and the role of artificial intelligence methods were examined. It also provided some examples of Al application to the reliability analysis of hybrid systems involving conventional and alternative energy sources. 
The author in (Kobbacy, 2012) found that relevant publications of Al applications in planning and modelling in maintenance started to appear from the mid 1980s.

In (Kobbacy, 2012), which is a good review of Al application in maintenance management, it is stated that during more than two decades (up to 2012) many attempts were made to apply Al techniques in maintenance modeling and management. The Al techniques used are numerous, ranging from classic expert systems that utilize rule based reasoning to more cumbersome optimization techniques used in Genetic Algorithms. It is stated that in the first decade of this century there was a shift towards developing hybrid intelligent management systems in operations that use more than one Al technique. The application areas of $\mathrm{Al}$ in maintenance extend widely from intelligent maintenance optimization models to more practical applications such as cost budgeting of maintenance projects and selecting optimal repair methods.

(Kobbacy, 2012) also presents an overview of the applications of Al techniques in maintenance, over the two decades, identifying specific applications and the extent of the use of techniques as well as near future trends. This was done by using the Science Direct database to carry out the literature search using the names of Al techniques, mostly using abstracts.

The author in (Kobbacy, 2012) classified artificial intelligence techniques in seven areas:

- Genetic Algorithms (GAs),

- Case Based Reasoning (CBR),

- Neural Networks (NNs),

- Knowledge Based Systems (KBs),

- Fuzzy Logic (FL),

- Data Mining (DM), and

- Hybrid Systems.

The review in (Kobbacy, 2012) showed that over the two decades, up to June 2012, many Al techniques were applied in maintenance management and modelling with the following conclusion:

- The most popular of the Al techniques applied in maintenance was GAs (due to its nature which offers powerful optimisation tools that can deal with complex maintenance planning problems),

- Both KBs and FL received moderate interest in maintenance applications, 
- A few applications were found on CBR and NNs in maintenance but none using DM (with the expectation that DM will be used in the future).

- A few hybrid systems were developed in the maintenance area, but the number of publications with FL and hybrid systems increased.

In (Cheng et al, 2008), which is included in the review (Kobbacy, 2012), in order to improve the efficiency of the reliability-centered maintenance (RCM) analysis, case-based reasoning (CBR), as a kind of artificial intelligence (AI) technology, was successfully introduced into the $\mathrm{RCM}$ analysis process, and the framework for the intelligent RCM analysis (IRCMA) was studied.

As an addition to the review from (Kobbacy, 2012), we will include some examples from sources after 2012, also using the Science Direct database and the key word artificial intelligence.

In (Blache, 2017), it is written about the case of Lufthansa Airlines, which maintains more than 1,000 planes and uses machine learning in real-time data collection and decision making, where recommended failure-avoidance actions come as a result of error messages and sensor data, among other things.

In (Diryag et al, 2014 ), the study presents a novel approach to a prediction of robot execution failures based on neural networks. Real data consisting of robot forces and torques recorded immediately after the system failure are used for neural network training. The multilayer feedforward neural networks are employed in order to find an optimal solution for the failure prediction problem.

In (Otto, 2019), it is concluded that emerging technologies such as the Internet of Things (IoT), Big Data, analytics, and cloud data storage are enabling more equipment to share condition-based data with a centralized server, making fault detection easier, more practical, and more direct.

Because this paper is motivated by the Strategy for the Development of Artificial Intelligence in the Republic of Serbia, it is worth mentioning that the Faculty of Mechanical Engineering (FME), in cooperation with the Faculty of Mathematics of the University of Belgrade, Serbia, organized a master study named Industry 4.0 in which two study subjects are dealing with artificial intelligence, and there is a possibility to apply it also in the area of reliability and maintenance, as the authors from the FME have already done in (Diryag et al, 2014 ). 
In (Bhargava, 2019), it is stated that Al Techniques for Reliability Prediction for Electronic Components provide emerging research exploring the theoretical and practical aspects of prediction methods using artificial intelligence and machine learning in the manufacturing field.

As mentioned before, the production process is also important for reliability. A poor quality production process can degrade reliability built in during the design phase. In (Alsina et al, 2018), it is studied how machine learning models can fit the reliability estimation function in comparison with traditional approaches (e.g., Weibull distribution), having in mind that the reliability estimation of engineered components is fundamental for many optimization policies in a production process. Four diverse machine learning approaches are implemented: artificial neural networks, support vector machines, random forest, and soft computing methods.

A new method for hull structural plate corrosion damage detection and recognition based on artificial intelligence using the convolutional neural network (CNN) is proposed in (Yao et al, 2019), which makes up for the research gap of applying deep learning into corrosion damage detection in the field of naval architecture and ocean engineering.

In (Zhao et al, 2019), data driven-based and knowledge drivenbased fault detection and diagnosis (FDD) methods for building energy systems are reviewed, and the strengths and shortcomings of the existing artificial intelligence-based methods are analysed.

In (Lee et al, 2019), the Al-based algorithms (data-driven modeling approach) for predictive maintenance are presented and applied to monitor two critical machine tool system elements: the cutting tool and the spindle motor.

Everyday life shows that faults of elements and systems are inevitable. But are near-zero-failure systems possible? In (Foresti et al, 2020), it is found that the results obtained in 12 international companies demonstrate a possible global standardization of operative processes, leading to the design of a near-zero-failure intelligent system that is able to learn and upgrade itself, which is exploitable in any context of Society 5.0 , thus reducing the risk factors at all management levels and ensuring quality and sustainability.

\section{Reliability of Al}

Everything can fail, and $\mathrm{Al}$ is not an exception. If $\mathrm{Al}$ is an attempt to replace human intelligence with machine intelligence, and human reasoning can sometimes fail, so Al can fail in a similar way. So, is the 
reason of erroneous reasoning (erroneous concluding, decisioning) in wrong learning? Or can we raise the question about the reliability of $\mathrm{Al}$, or how to avoid Al fails?

This is an important question which attracted the attention of ISO/IEC. In (ISO, 2020), there are surveys of topics related to the so-called trustworthiness in Al systems, including the following: (1) approaches to establish trust in Al systems through transparency, explainability, controllability, etc.; (2) engineering pitfalls and typical associated threats and risks to Al systems, along with possible mitigation techniques and methods; and (3) approaches to assess and achieve availability, resiliency, reliability, accuracy, safety, security, and privacy of Al systems. In this document, trustworthiness is defined as an ability to meet stakeholders expectations in a verifiable way, including the characteristics of trustworthiness such as reliability, availability, resilience, security, privacy, safety, accountability, transparency, integrity, authenticity, quality, and usability.

(Heaven, 2019) discussed why deep learning Al is so easy to fool. An example is in a self-driving car application in a real situation. It is, however, said that ih can happen in the case of sabotage as well.

In (University of Cambridge, 2016) under the headline "Enhanching the reliabiliy of artificial intelligence", it is stated that "Computers that learn for themselves are with us now. As they become more common in 'high-stakes' applications like robotic surgery, terrorism detection and driverless cars, researchers ask what can be done to make sure we can trust them." So, are they reliable? Or, can they fail?

There are examples of erroneous Al. Some examples can be found in (Bathaee, 2018): Al failures from IBM, Microsoft, Apple, and Amazon. The example from IBM happened in 2013, when IBM partnered with the University of Texas MD Anderson Cancer Center which developed a new "Oncology Expert Advisor" system with the goal to cure cancer (Blier, 2020). In July 2018, StatNews reviewed internal IBM documents and found that IBM's Watson was making erroneous, downright dangerous cancer treatment advice. In (Bathaee, 2018), it is concluded that, probably, the reason is because the software is trained on a small number of hypothetical cancer patients, rather than on real patient data.

There are authors who ask questions about potential risks, such as whether $\mathrm{Al}$ will pose an existential threat to humanity, or whether $\mathrm{Al}$ technology will be concentrated in the hands of the few (Bathaee, 2018), but this author thinks that is not the question of $\mathrm{Al}$ application in the area of reliability and maintainability, at least not in the near future. 
There is also a question raised whether $\mathrm{Al}$ can fail to function as expected, and the reason is because of the nature of the machinelearning algorithms on which modern Al techniques are commonly built. These algorithms are capable of learning from massive amounts of data, and once that data is internalized, they are capable of making decisions experientially or intuitively like humans. This means that for the first time, computers are no longer merely executing detailed pre-written instructions but are capable of arriving at dynamic solutions to problems based on patterns in data that humans may not even be able to perceive. This new approach comes at a price, because many of these algorithms can be black boxes, even to their creators (Bathaee, 2018). But in the area of maintenance, the problem is more often that we do not have enough data.

One of the important questions is whether Al can work on a small number of data, for example, the number of failures. In (Microsoft, 2020), it is concluded that model's predictive accuracy depends on the relevancy, sufficiency, and quality of the training and test data. Two questions are commonly asked with regard to failure history data: (1) How many failure events are required to train a model? And (2) How many records is considered as "enough"? (Microsoft, 2020).

As a conclusion for Al reliability, or trustworthiness (which is a broader term), let us use the statement from (Draft, 2020): „Having the capability to generate tremendous benefits for individuals and society, Al also gives rise to certain risks that should be properly managed, and "It is known that humans are biased in their decision making. Since Al systems are designed by humans, it is possible that humans inject their bias into them, even in an unintended way."

\section{Maintaining of $\mathrm{Al}$}

An Al system also needs maintenance, not only because Al can fail. In (Blier, 2020), Al is compared to a car engine in a way that maintaining Al can be as easy as replacing the cabin air filter, or as complicated as rebuilding the transmission, and that is considered as a reason why it is important to understand some basic Al maintenance best practices.

So, just like any other product, $\mathrm{Al}$ requires maintenance to remain robust and valuable, and as a car, Al can experienced a sudden, catastrophic failure if it is not kept up-to-date.

To build successful Al, there is a need to be familiar with cases when $\mathrm{Al}$ initiatives failed in order not to make the same mistakes. Also there is a need to be familiar with data science. 


\section{Conclusion}

Progress in $\mathrm{Al}$ is inevitable, so it is important to understand its potentials for the application in reliability and maintenance and also possible pitfalls of it.

The review of the available literature shows that $A I$ is more applied in maintenance than in reliability. Kobbacy's paper gives a good review of Al application in maintenance management at the end of the last century and the beginning of this century. It shows that the most popular techniques in maintenance were Genetic Algorithms, then Knowledge Based Systems (or expert systems) and Fuzzy Logic with moderate interest, and Case Based Reasoning, Neural Networks and Hybrid Systems with only a few applications. Nowadays, there is much more interest in machine learning (as a subset of $\mathrm{Al}$ ), deep learning (as a subset of machine learning), and intelligent agents. Machine learning and intelligent agents can be applied more in reliability and predictive maintenance in the future.

Artificial intelligence can be applied in reliability and maintenance. In both cases, a problem is data. The problem is how to cope with large amounts of data on the one hand, and with very small amounts of data on the other hand, because both can be the case in reliability and maintenance.

Everything can fail, and $\mathrm{Al}$ is not an exception. So, an Al system also needs maintenance. Also, an important question is how to avoid failure of $\mathrm{Al}$.

\section{References}

Alsina, E.F., Chica, M., Trawinski, K. \& Regattieri, A. 2018. On the use of machine learning methods to predict component reliability from data-driven industrial case studies. The International Journal of Advanced Manufacturing Technology, 94, pp.2419-2433. Available at: https://doi.org/10.1007/s00170-0171039-x.

Bathaee, Y. 2018. The Artificial Intelligence Black Box and the Failure of Intent and Causation. Harvard Journal of Law \& Technology, 31(2) [online]. Available at: https://jolt.law.harvard.edu/assets/articlePDFs/v31/The-ArtificialIntelligence-Black-Box-and-the-Failure-of-Intent-and-Causation-Yavar-

Bathaee.pdf [Accessed: 15.01.2021].

Bauer, E. \& Adams, R. 2012. Reliability and Availability of Cloud Computing. Hoboken, NJ: John Wiley \& Sons. ISBN: 978-1-118-17701-3. 
Bhargava, C. 2019. Al Techniques for Reliability Prediction for Electronic Components. Hershey, PA: IGI Global. Available at: https://doi.org/10.4018/9781-7998-1464-1. ISBN: 9781799814641

Blache, K.M. 2017. Al and Reliability: How Much, How Fast? Efficient Plant, 14 November [online] Available at: https://www.efficientplantmag.com/2017/11/ai-reliability-much-fast/ [Accessed: 15.01.2021].

Blier, N. 2020. Stories of Al Failure and How to Avoid Similar Al Fails. Lexalytics, $\quad 30$ January [online]. Available at: https://www.lexalytics.com/lexablog/stories-ai-failure-avoid-ai-fails-2020 [Accessed: 15.01.2021].

Cheng, Z., Jia, X., Gao, P., Wu, B. \& Wang, J. 2008. A framework for intelligent reliability centered maintenance analysis. Reliability Engineering \& System Safety, 93(6), pp.806-814. Available at: https://doi.org/10.1016/j.ress.2007.03.037.

Copeland, B.J. 1998. Artificial intelligence In: Encyclopedia Britannica. London: Encyclopedia Britannica, Inc. [online]. Available at: https://www.britannica.com/technology/artificial-intelligence [Accessed: 15.01.2021].

Diryag, A., Mitić, M. \& Miljković, Z. 2014. Neural Networks for Prediction of Robot Failures. In: Proceedings of the Institution of Mechanical Engineers, Part C: Journal of Mechanical Engineering Science, 228(8), pp.1444-1458. Available at: https://doi.org/10.1177/0954406213507704.

-European Commission. 2019. A definition of Al: Main capabilities and scientific disciplines. Brussels: European Commission Independent High-Level Expert Group on Artificial Intelligence [online]. Available at: https://ec.europa.eu/digital-single-market/en/news/definition-artificialintelligence-main-capabilities-and-scientific-disciplines [Accessed: 15.01.2021].

Foresti, R., Rossi, S., Magnani, M., Lo Bianco, C.G. \& Delmonte, N. 2020. Smart society and artificial intelligence: big data scheduling and theglobal standard method applied to smart maintenance. Engineering, 6(7), pp.835-846. Available at: https://doi.org/10.1016/j.eng.2019.11.014.

-Government of the Republic of Serbia. 2019. Strategy for the Development of Artificial Intelligence in the Republic of Serbia for the period 2020-2025 [online]. Available at: https://www.srbija.gov.rs/tekst/en/149169/strategy-for-thedevelopment-of-artificial-intelligence-in-the-republic-of-serbia-for-the-period2020-2025.php [Accessed: 15.01.2021].

Heaven, D. 2019. Why deep-learning Als are so easy to fool. Nature, 09 October [online]. Available at: https://www.nature.com/articles/d41586-01903013-5 [Accessed: 15.01.2021].

-ISO. 2020. ISO/IEC TR 24028:2020 Information technology - Artificial intelligence - Overview of trustworthiness in artificial intelligence [online]. Available at: https://www.iso.org/standard/77608.html?browse=tc [Accessed: 15.01.2021]. 
Kobbacy, K.A.H. 2012. Application of Artificial Intelligence in Maintenance Modelling and Management. IFAC Proceedings Volumes, 45(31), pp.54-59. Available at: https://doi.org/10.3182/20121122-2-ES-4026.00046.

Lee, W.J., Wu, H., Yun, H., Kim, H., Jun, M.B.G. \& Sutherland, J.W. 2019. Predictive Maintenance of Machine Tool Systems Using Artificial Intelligence Techniques Applied to Machine Condition Data. Procedia CIRP, 80, pp.506-511. Available at: https://doi.org/10.1016/j.procir.2018.12.019.

-Merriam-Webster. 2020. Artificial intelligence. In: MerriamWebster.com dictionary [online]. Available at: https://www.merriamwebster.com/dictionary/artificial\%20intelligence [Accessed: 15.01.2021].

-Microsoft. 2020. Azure Al guide for predictive maintenance solutions [online]. Available at: https://docs.microsoft.com/en-us/azure/machinelearning/team-data-science-process/predictive-maintenance-playbook

[Accessed: 15.01.2021].

Otto, S. 2019. Artificial intelligence for predictive maintenance. Aerospace Manufacturing and Design, 6 Febrauary [online]. Available at: https://www.aerospacemanufacturinganddesign.com/article/artificial-intelligencefor-predictive-maintenance. Accessed: 15.01.2021.

Pokorni, S. 2016. Reliability prediction of electronic equipment: problems and experience. In: $7^{\text {th }}$ International Scientific Conference on Defensive Technologies OTEH 2016, Belgrade, pp.695-700, 6-7 October. ISBN 978-8681123-82-9.

Pokorni, S. 2018. Reliability of Internet of Things. In: $8^{\text {th }}$ International Scientific Conference on Defensive Technologies OTEH 2018, Belgrade, pp.567-570, 11-12 October [online]. Available at: http://www.vti.mod.gov.rs/oteh18/elementi/rad/027.htm. ISBN 978-86-81123-884. [Accessed: 15.01.2021].

Pokorni, S. 2020. Artificial Intelligence in Reliability and Maintainability. In: $9^{\text {th }}$ International Scientific Conference on Defensive Technologies OTEH 2020 , Belgrade, 15-16 October [online]. Available at: http://www.vti.mod.gov.rs/oteh/elementi/rad/114.pdf [Accessed: 15.01.2021].

Richards, D.W. 1989. Smart BIT: A plan for intelligent built-in test. IEEE Aerospace and Electronic Systems Magazine, 4(1), pp.26-29. Available at: https://doi.org/10.1109/62.16985.

Siladić, M., Pokorni, S. \& Rašuo, B. 2003. Possibility of improvement of jet engine diagnostic by applying neural networks (in Serbian). In: Proceeding of XLVII ETRAN Conference, Herceg Novi, June 8-13, Vol. I.

Singh, C. \& Wang, L. 2008. Role of Artificial Intelligence in the Reliability Evaluation of Electric Power Systems. Turkish Journal of Electrical Engineering and Computer Science, 16(3), [online]. Available at: http://journals.tubitak.gov.tr/elektrik/issues/elk-08-16-3/elk-16-3-2-0808-7.pdf [Accessed: 15.01.2021].

-University of Cambridge. 2016. Enhancing the reliability of artificial intelligence [online]. Available at: https://phys.org/news/2016-10-reliabilityartificial-intelligence.html [Accessed: 15.01.2021]. 
-Uptake. 2020. How Al is Making Predictive Maintenance a Reality for the Industrial IoT [online]. Available at: https://www.uptake.com/blog/how-ai-ismaking-predictive-maintenance-a-reality-for-the-industrial-iot [Accessed: 15.01.2021].

Yao, Y., Yang, Y., Wang, Y. \& Zhao, X. 2019. Artificial intelligence-based hull structural plate corrosion damage detection and recognition using convolutional neural network. Applied Ocean Research, 90(art.number:101823). Available at: https://doi.org/10.1016/j.apor.2019.05.008.

Zhao, Y., Li, T., Zhang, X. \& Zhang, C. 2019. Artificial intelligence-based fault detection and diagnosis methods for building energy systems: Advantages, challenges and the future. Renewable and Sustainable Energy Reviews, 109, pp.85-101. Available at: https://doi.org/10.1016/j.rser.2019.04.021.

ПРИМЕНЕНИЕ ИСКУССТВЕННОГО ИНТЕЛЛЕКТА В ОБЛАСТЯХ НАДЕЖНОСТИ И ОБСЛУЖИВАНИЯ

Славко Й. Покорни

Колледж информационных технологий, г. Белград, Республика Сербия

РУБРИКА ГРНТИ: 28.00.00 КИБЕРНЕТИКА:

28.23.00 Искусственный интеллект,

28.27.00 Теория надежности,

81.00.00 ОБЩИЕ И КОМПЛЕКСНЫЕ ПРОБЛЕМЫ

ТЕХНИЧЕСКИХ И ПРИКЛАДНЫХ НАУК И ОТРАСЛЕЙ НАРОДНОГО ХОЗЯЙСТВА:

81.88.00 Материально-техническое снабжение. Логистика

ВИД СТАТЬИ: оригинальная научная статья

Резюме:

Введение/цель: В конце 2019 года Правительство Республики Сербия утвердило Стратегию развития искусственного интеллекта в Республике Сербия за период 2020-2025 годов. Настоящий фракт побудил автора данной статьи попытаться дать в ней обзор действующих приложений искусственного интеллекта (ИИ) в области надежности и обслуживания, а также разрабатываемых приложений.

Методы: Обзор составлен на основании доступной литературы, в основном из базы данных Science Direct, в первую очередь использовались аннотации, а в некоторых случаях и целые cmambu.

Результаты: В результате проведенного исследования был составлен обзор приложений искусственного интеллекта в области надежности и обслуживания за последние тридиать лет. Исследование показало, что система искусственного интеллекта может оказаться ненадежной и требует обслуживания. 
Выводы: Искусственный интеллект применяется и может применяться для обеспечения надежности и в области обслуживания. Исследование доступной литературы показало, что ИИ в большей мере применяется в области обслуживания, нежели в области надежности. Прогресс в области искусственного интеллекта неизбежен, поэтому важно понимать его возможности для применения в срере надежности и обслуживания, а также возможные препятствия, с целью их преодоления.

Ключевые слова: искусственный интеллект, надежность, ремонтопригодность, обслуживание.

\section{ПРЕГЛЕД СТАҢА ВЕШТАЧКЕ ИНТЕЛИГЕНЦИЈЕ У ПОУЗДАНОСТИ И ОДРЖАВАЊУ}

\section{Славко Ј. Покорни}

Висока школа струковних студија за информационе технологије,

Београд, Република Србија

ОБЛАСТ: логистика, информатика

ВРСТА ЧЛАНКА: оригинални научни чланак

Сажетак:

Увод/циљ: Крајем 2019. године Влада Републике Србије усвојила је Стратегију развоја вештачке интелигенције у Републици Србији за период 2020-2025. године. С тим увези, у овом раду је представљен преглед тренутних примена апликација вештачке интелигенције (ВИ) у области поузданости и одржавања, као и будућих примена.

Методе: Истраживање је реализовано захваљујући доступној литератури, углавном из базе података Science Direct, коришћењем апстракта, а у неким случајевима и читавих радова.

Резултати: Резултат овог истраживања је преглед примена апликација вештачке интелигенције у области поузданости и одржавања у последњих тридесет година. Такође, показано је да систем ВИ може бити непоуздан и да му је потребно одржавање.

Закључак: Вештачка интелигенција може се применити и у поузданости и одржавању. Из доступне литературе може се закључити да се ВИ чешће примењује у одржавању него у поузданости. Напредак у ВИ је неизбежан, па је важно разумети његове потенцијале за примену у поузданости и одржавању, као и могуће замке.

Кључне речи: вештачка интелигенција, поузданост, погодност одржавања, одржавање. 
Paper received on / Дата получения работы / Датум пријема чланка: 20.01.2021. Manuscript corrections submitted on / Дата получения исправленной версии работы / Датум достављања исправки рукописа: 19.04.2021.

Paper accepted for publishing on / Дата окончательного согласования работы / Датум коначног прихватања чланка за објављивање: 21.04.2021.

(C) 2021 The Author. Published by Vojnotehnički glasnik / Military Technical Courier (www.vtg.mod.gov.rs, втг.мо.упр.срб). This article is an open access article distributed under the terms and conditions of the Creative Commons Attribution license (http://creativecommons.org/licenses/by/3.0/rs/).

() 2021 Автор. Опубликовано в «Военно-технический вестник / Vojnotehnički glasnik / Military Technical Courier» (www.vtg.mod.gov.rs, втг.мо.упр.срб). Данная статья в открытом доступе и распространяется в соответствии с лицензией «Creative Commons» (http://creativecommons.org/licenses/by/3.0/rs/).

(c) 2021 Аутор. Објавио Војнотехнички гласник / Vojnotehnički glasnik / Military Technical Courier (www.vtg.mod.gov.rs, втг.мо.упр.срб). Ово је чланак отвореног приступа и дистрибуира се у складу са Creative Commons лиценцом (http://creativecommons.org/licenses/by/3.0/rs/).

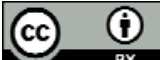

